\title{
Problems-Based Module Development on Alkene and Alkyne Materials in the Senior High School
}

\author{
Ratu Evina Dibyantini \\ Department of Chemistry Education \\ State University of Medan \\ Medan, Indonesia \\ E-mail: ratuevina1962@gmail.com
}

\author{
Widya Astuti \\ Graduate of Department of Chemistry Education \\ State University of Medan \\ Medan, Indonesia \\ E-mail: widyacane@gmail.com
}

\begin{abstract}
This study was aimed to find out: 1) problem-based developed module met the criteria of National Education Standard Board (BSNP), 2) the implementation of problem-based learning model supported by developed module could improve student learning outcomes, 3) the students' learning outcomes which used problem-based module was greater than the grade of minimum criteria of mastery learning (KKM). This study had been done to students of class XI Science-1 in the State Senior High School 9 of Medan. The population was all students of class XI Science consisting of four classes. The sample was determined by cluster random sampling by taking one class as the experimental class. This research was using research and development method. The results showed (1) developed module on alkenes and alkynes materials met BSNP criteria, data obtained: feasibility content $=3.52$; feasibility of language $=3.40$; Feasibility of Presentation $=3.53$; feasibility of graph $=3.59$ with valid criteria and no revisions required; (2) the implementation of problem-based learning model supported by developed module were able to improve student learning outcomes by $72 \%$; (3) student learning outcomes using problem-based module was greater than KKM score.
\end{abstract}

Keywords: research and development, problems based module.

\section{INTRODUCTION}

Based on the observation done by Hilmi, chemistry was one of the complicated subjects for students. This belief was caused by the need of direct experience in learning chemistry. Throughout this time, students were only accepting information that given by teachers but they did not get involved in the process of finding the knowledge itself, as well as the lack of skill in applying their knowledge in facing life issues and technology [1].

Many efforts had been done by the governments to improve educational system in order to fit in times and to create competitive individuals, such as: teacher quality improvement, facilities and infrastructure improvement, curriculum changing, improvement of scoring system as well as the use of appropriate teaching model and method [2].

One of the efforts to improve facilities and infrastructure was by procuring quality teaching materials in choosing or deciding the appropriate teaching materials in order to help students to reach the competency. Teaching material is very important in teaching learning process. It would help teachers to achieve learning objectives and fulfil basic competencies. Thus the results of observations conducted by researchers in the field was the very minimum quality of chemistry materials that fit the curriculum or syllabus becomes a problem often faced by educators in learning activities. One of the efforts to improve the quality of learning is through the procurement of quality materials by selecting or choosing the right teaching materials in order to help learners achieve competence [3]. The development of teaching materials should be based on the prerequisites of the competent authority of the National Education Standards Board (BSNP), and the applicable curriculum [4].

As for the types of instructional materials such as visual materials consist of print materials such as handouts, books, module, student worksheets, brochures, leafleat, wallchart, photo / picture, non printed, such as model / maket [5]. According to Majid, module is a book written with the purpose that students can learn independently without or with teacher guidance. A module will be meaningful if students are able to use it easily. Learning with module enables students to complete one or more basic competencies more quickly than the other students. Thus, the module should describe the basic competencies to be achieved by the students, presented using proper grammar, attractive, with illustrations [6].

Innovation in teaching materials can be developed with the right learning model to encourage students to master the concept of application in everyday life. The presentation of the material which is not equipped with the integration of the right learning model tends to be monotonous and boring, it makes the basic concept of chemistry becomes less interesting and more difficult to be understood by the students. The solution of the matter is the module teaching materials must be integrated in an interesting learning model that can make the students more active. One of the learning models that can be an alternative choice is the Problem Based Learning model [7].

In using the problem-based learning model requires students to identify problems, gather information and use that information to solve problems. Focused problem-based 
learning, in which students begin to observe, analyze and summarize the results of observations independently [2]. Through these activities, students' activities and their scientific thinking processes become more logical, organized, and detailed that they facilitate the understanding of the concept [8]. In the PBL a small group of 6 or 8 students is led by a tutor. They are given an authentic, complex problem to help students make connections between theories and real-world applications, as well as develop their ability to handle the complexities of the real world [9]. Problem-Based Learning Model is a teaching model characterized by creative thinking skills, critical and problem-solving skills which will arise if supported by a learner-centered learning environment, so that learners are freely to express ideas that arise within themselves [10].

Several studies have shown that using chemistry module integrated with problem-based learning models has a positive impact on learning activities, on research conducted by Sunaringtyas on the development of problem-based chemistry module on mole concept material was feasible in the learning process and effective to improve knowledge learning outcomes, skills and attitudes with validator judgments on feasibility aspects of content 4.3, feasibility of language 4.3, feasibility of presentation 4.3 and feasibility of graphic 4.1, it means that the problem-based chemistry module was valid and no revision required [11].

According to Khotim research that showed the problembased chemical module on acid base material was feasible and effective to be used as a students' learning resource with expert judgments obtained very feasible criteria of material experts 3.82, language experts 3.69 , and presentation experts 3,9 which means that the chemistry learning module was valid and no revision required [8].

This study was aimed to determine: (1) developed module met the criteria of BSNP; (2) the implementation of problembased learning model supported by developed module could improve student learning outcomes; (3) student learning outcomes using integrated module based learning model was greater than the score of minimum criteria of mastery learning (KKM).

\section{RESEARCH METHOD AND RESULT}

This research was carried out at SMA Negeri 9 Medan in the class XI Science of the academic year 2015 / 2016. It consisted of 4 classes with the number of students 160 people where each class had 40 people. Sample in this research was taken by random technique of cluster random sampling that was done to sampling unit (individual), where the sampling unit was in one cluster. Each unit (individual) within the selected group was taken as a sample. In this study, one group was taken as a sample by drawing 1 sample class.

This study was a developmental research (Research and Development) which was modified from the development of
Borg \& Gall learning model. Research and development methods are research methods used to produce a particular product, and to test the effectiveness of the product [4]. The product developed was a problem-based module on alkenes and alkynes materials in senior high school program.

The procedures of this study were conducted following a research procedure that had been done by previous researchers Sunaringtyas [11]. It consisted of several stages, including: (1) analyzing the chemistry books of alkenes and alkynes materials commonly used in senior high schools; (2) designing and developing module based on the alkenes and alkynes materials; (3) standardization of developed module; 4) test module that had been developed. Research procedures are briefly described in Figure 1.

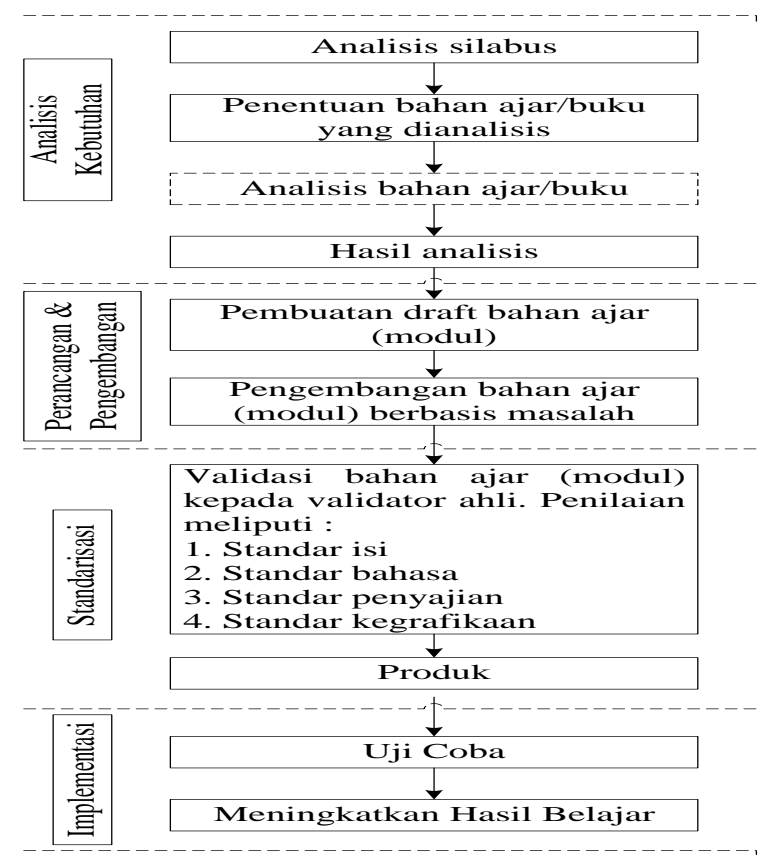

Fig. 1. The research procedure of problem-based module development on alkenes and alkynes material.

The revised module was then printed as necessary to be used in helping students study the material of alkenes and alkynes. The developed module was used for alkenes and alkynes chemistry learning in class XI students of senior high school for the experimental group and no control class as the comparison group. In order to find out the level of initial knowledge, pretest was conducted then learning was done by using problem-based learning model and the use of problembased module, learning evaluation (posttest) was done at the end of learning process. 


\section{RESULT AND DISCUSSION}

1. Result

a. Chemistry Book Analysis by Lecturer Respondent

The results of the analysis of three chemistry books by lecturer respondents are presented in table 2.

TABLE I. THE ANALYSIS RESULTS OF THREE CHEMISTRY BOOKS BY LECTURER RESPONDENTS

\begin{tabular}{|c|c|c|c|c|c|}
\hline \multirow{2}{*}{$\begin{array}{c}\text { Text } \\
\text { Book }\end{array}$} & \multicolumn{4}{|c|}{ Average Score of Materials Conformity } & \multirow{2}{*}{ Average } \\
\cline { 2 - 5 } & $\begin{array}{c}\text { Feasibility } \\
\text { of } \\
\text { Content }\end{array}$ & $\begin{array}{c}\text { Feasibility } \\
\text { of } \\
\text { Language }\end{array}$ & $\begin{array}{c}\text { Feasibility } \\
\text { of } \\
\text { Presentation }\end{array}$ & $\begin{array}{c}\text { Feasibility } \\
\text { of Graphics }\end{array}$ & \\
\hline Book 1 & 3,09 & 3,09 & 2,87 & 2,90 & 3,00 \\
\hline Book 2 & 3,16 & 3,16 & 2,95 & 3,01 & 3,03 \\
\hline Book 3 & 2,89 & 3,89 & 2,65 & 2,79 & 2,80 \\
\hline
\end{tabular}

Based on the data above, it can be seen that the analysis of three chemistry books analyzed by the respective lecturers respondents have advantages and disadvantages both in terms of the feasibility of content, language feasibility, feasibility of presentation, and feasibility of graphics. Assessment of the feasibility of the content, language feasibility, feasibility of presentation, and feasibility of graphics on three chemistry books gave different results. Based on the data from the analysis of three chemical books (book 1, book 2, and book 3 ), the comparison graph of analysis result of three chemical books are obtained as follows:

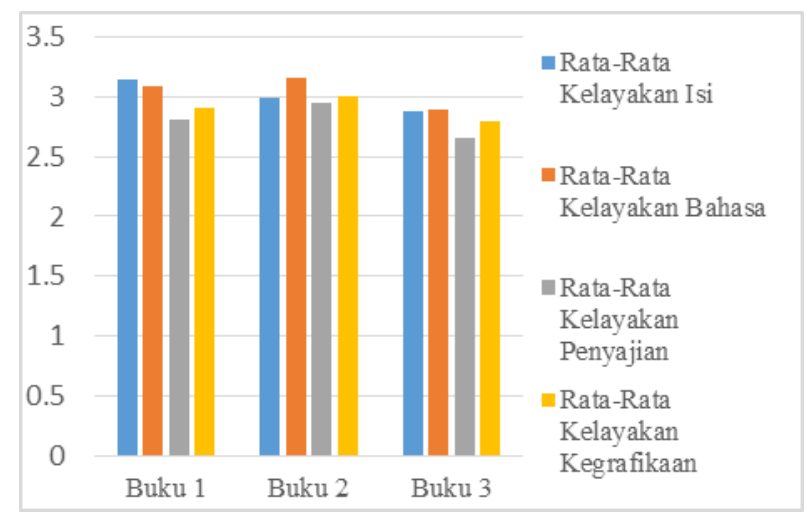

Fig. 2. Graph of analysis result of three chemistry book by lecturer

\section{b. Module Standardization}

After the development of the alkenes and alkynes module was completed, the next step was to standardize the problem-based module. Standardization was performed by expert validators by using BSNP instrument in order to obtain the results of assessment and improvement suggestions. The module standardization was done by five expert validators consisted of three lecturers of Chemistry Department FMIPA UNIMED and two chemistry teachers of SMA Negeri Medan. The assessment result of problem based module on alkenes and alkynes developed material is presented in table 3 .

TABLE II. MODULE STANDARDIZATION RESULT

\begin{tabular}{|c|c|c|c|}
\hline No. & Criteria & Average & Validation Criteria \\
\hline 1. & $\begin{array}{c}\text { Feasibility of } \\
\text { Content }\end{array}$ & 3,52 & $\begin{array}{c}\text { valid and no revision } \\
\text { required }\end{array}$ \\
\hline 2. & $\begin{array}{c}\text { Feasibility of } \\
\text { Language }\end{array}$ & 3,42 & $\begin{array}{c}\text { valid and no revision } \\
\text { required }\end{array}$ \\
\hline 3. & $\begin{array}{l}\text { Feasibility of } \\
\text { Presentation }\end{array}$ & 3,53 & $\begin{array}{c}\text { valid and no revision } \\
\text { required }\end{array}$ \\
\hline 4. & $\begin{array}{c}\text { Feasibility of } \\
\text { Graphics }\end{array}$ & 3,59 & $\begin{array}{c}\text { valid and no revision } \\
\text { required }\end{array}$ \\
\hline & Average & 3,52 & $\begin{array}{c}\text { valid and no revision } \\
\text { required }\end{array}$ \\
\hline
\end{tabular}

The results of problem assessment in problem-based module that have been developed are:

TABLE III. THE RESULT OF PROBLEMS ASSESSMENT ON PROBLEM BASED MODULE

\begin{tabular}{|c|c|c|c|}
\hline No & $\begin{array}{c}\text { Assessment } \\
\text { Component }\end{array}$ & $\begin{array}{c}\text { Assessment } \\
\text { Results }\end{array}$ & Criteria \\
\hline 1 & Reliability & 3,80 & $\begin{array}{c}\text { valid and no revision } \\
\text { required }\end{array}$ \\
\hline 2 & $\begin{array}{c}\text { Curiousity } \\
\text { Stimulation }\end{array}$ & 3,70 & $\begin{array}{c}\text { valid and no revision } \\
\text { required }\end{array}$ \\
\hline 3 & Communicative & 3,60 & $\begin{array}{c}\text { valid and no revision } \\
\text { required }\end{array}$ \\
\hline 4 & $\begin{array}{c}\text { Dialogical dan } \\
\text { interactive }\end{array}$ & 3,40 & $\begin{array}{c}\text { valid and no revision } \\
\text { required }\end{array}$ \\
\hline 5 & $\begin{array}{c}\text { Technique of } \\
\text { Presentation }\end{array}$ & 3,60 & $\begin{array}{c}\text { valid and no revision } \\
\text { required }\end{array}$ \\
\hline 6 & $\begin{array}{c}\text { Learning } \\
\text { Presentation }\end{array}$ & 3,60 & $\begin{array}{c}\text { valid and no revision } \\
\text { required }\end{array}$ \\
\hline & Average & $\mathbf{3 , 6 2}$ & $\begin{array}{c}\text { valid and no revision } \\
\text { required }\end{array}$ \\
\hline
\end{tabular}

\section{c. Student Learning Outcomes}

Student learning outcomes in the experimental class was 85.7 and the learning improvement (gain) obtained by $72 \%$. In testing the hypothesis one party statistical test which was called t right was used, the hypothesis testing that would be tested was hypothesis testing of chemistry learning outcomes by using problem based learning model integrated module was bigger than KKM score. Testing criteria if $t_{\text {obs }}>t_{\text {table }}$ means alternative hypothesis is accepted and null hypothesis is rejected.

The data of hypothesis test result can be seen in table 4 . 
TABLE IV. THE RESULT OF HYPOTHESIS TESTING OF LEARNING OUTCOMES WITH KKM SCORE

\begin{tabular}{|l|c|c|c|}
\hline \multicolumn{1}{|c|}{$\begin{array}{c}\text { Posttest Data of } \\
\text { Experimental Class }\end{array}$} & $\mathbf{T}_{\text {observe }}$ & $\mathbf{t}_{\text {table }}$ & Explanation \\
\hline $\bar{X}=85,7$ & & & \\
$\mu_{0}=75$ & 7,043 & 1,684 & Ha accepted \\
$\mathrm{s}=9,19$ & & & \\
$\mathrm{n}=36$ & & & \\
\hline
\end{tabular}

\section{Discussion}

The analysis of three chemistry books was obtained in Book 1; the feasibility of the content with the result 3.14, for the language feasibility reach the score of 3.09 , for the feasibility of the presentation reach the score of 2.87 , and for the feasibility of graphics reach the score of 2.90 , so that the average score is 3.00. In Book 2; the feasibility of the contents reach the score of 2.99 , for the feasibility of the language reach the score of 3.16 , for the feasibility of the presentation reach the score of 2.95, and for the feasibility of graphics reach the score of 3.01, so that the average score is 3.03. In Book 3; the feasibility of the contents reach the score of 2.88 , for the language feasibility reach the score of 2.89 , for the feasibility of presentation reach the score of 2.65 , and for the feasibility of graphics reach the score of 2.79 , so the average score is 2.80 . It can be concluded that the analysis results of the three chemistry books achieve quite valid criteria and no revision required.

The result of problem based module standardization on alkenes and alkynes material was done by validators who are 3 chemistry lecturers and 2 chemistry teachers, can be seen in table 3, overall respondents gave positive respond to alkenes and alkynes integrated problem module. It can be seen from the average rating from validator on the alkenes and alkyness module, namely the feasibility of content reach the score of 3.52 with valid and unnecessary revised criteria, for the feasibility of language reach the score of 3.42 with valid and unnecessary revised criteria, for the feasibility of presentation reach the score of 3,53 with valid criteria and no revision required, and for feasibility of graphics reach the score of 3.59 with valid criteria and do not need to be revised, so that average score is 3.52. It means that the assessment of problem-based module on alkenes and alkynes material is valid and no revision required.

The result of problem assessment on the problembased module can be seen in table 4 with the highest score on the reliability components with an average score of 3.80 which means valid and no need revision while the lowest score on the dialogical and interactive components with the average score of each 3.40 which means valid and no revision required. The curiosity stimulation components got an average score of 3.70 which means valid and no revision required. Communicative stimulation components got an average score 3,60 which means 3,60 valid and no revision required.
Technique of presentation components got an average score of 3,60 which means valid and no revision required. The result of problem asessement average score on problem based module of chemistry development is 3.62. This means problem in problem based module is valid and no revision required.

This study was using a developmental research (Research and Development) that is developing problem based module on akenes and alkynes material. The hypothesis used in this study is students' chemistry learning outcomes by using problem based learning model with integrated module is greater than KKM score. The hypothesis proposed was then being tested statistically based on the research data that has been obtained. Before the hypothesis test was done, the prerequisite analysis was obtained by doing the the normality test and homogeneity test, in which the prerequisite being tested was the score of pretest, postest, and the improvement of learning outcomes. Based on the normality test, the data was normally distributed and from the homogeneity test, the data was homogeneous. After both tests were done, the hypothesis test was tested by one party (right side) to see the improvement of student learning outcomes.

Based on the result of the research, it was found that the average score of the pre-test in the experimental class was 37,8. Next, post-test were given. Based on the test results, the average score of the post-test in the experimental class was 85,7 . It shows that in this study there was an improvement in learning outcomes about $72 \%$ in experimental class. In addition, if it was seen from the KKM determined by the school, the test results also show that the experimental class successfully reached and exceeded the existing KKM of 75 determined based on the students' average score. This meant that $\mathrm{Ha}$ is accepted and Ho is rejected, which stated that the result of learning chemistry using the development of problem-based chemistry module was greater than KKM score.

The results of this study were in line with the research conducted by Khotim which showed that the development of problem-based chemistry module had been revised based on suggestions and inputs from expert validators, and had been tested to candidate of the module users (student). The development of problem-based chemistry module is appropriate to be used in learning process and effectively improve students learning outcomes [5].

So based on research conducted in SMA Negeri 9 Medan, it can be concluded that problem-based learning integrated problem-based module were effectively improve student learning outcomes.

\section{CONCLUSION}

1. The developed module meets BSNP criteria, with data processing obtained: feasibility of context $=3,52$; feasibility of language $=3,40$; feasibility of presentation $=$ 
3,53 ; feasibility of graphics $=3,59$ means valid and no revision required.

2. The implementation of problem-based learning model supported by developed module was able to improve student learning outcomes on alkenes and alkynes materials.

3. Based on the conducted research and existing data processing, it was found that the student learning outcomes using problem-based module was greater than KKM score.

\section{REFERENCES}

[1] Hilmi, M., Ikawati, A., Nurhayati, A., dan Widodo, A.T., (2015), Penerapan Model Based Learning Untuk Meningkatkan Aktivitas dan Ketercapaian Kompetensi Siswa, Chemistry in Education 4 (2): 43-49

[2] Assriyanto, K.E., Sukardjo, J.S., dan Saputro, S., (2014), Pengaruh Model Pembelajaran Berbasis Masalah Melalui Metode Eksperimen dan Inkuiri Terbimbing Ditinjau dari Kreativitas Siswa Pada Materi Larutan Penyangga di SMA N 2 Sukoharjo Tahun Ajaran 2013/2014, Jurnal Pendidikan Kimia 3(3) : 89-97.

[3] Gultom, E., (2015), Pengembangan Bahan Ajar Inovatif dan InteraktifMelalui Pendekatan Saintifik Pada Pengajaran Termokimia, Laporan Hasil Penelitian, Pendidikan Kimia Pascasarjana Universitas Negeri Medan.

[4] Haryati, S., (2012), Research and Development (R\&D) Sebagai Salah Satu Model Penelitian Dalam Bidang Pendidikan, Jurnal Education, 37(1) : 11-26

[5] Nugraha, D,A., (2013), Penembangan Bahan Ajar Redoks Bervisi Sets, Berorientasi Konstruktivistik, Journal of Innovative Science Education 2(1) : 27 -34
[6] Majid, A., (2011), Perencanaan Pembelajaran Mengembangkan Standar Kompetensi Guru, PT Remaja Rosdakarya, Bandung.

[7] Khotim, H.N., Nurhayati, S., dan Hadisaputro, S., (2015), Pengembangan Modul Kimia Berbasis Masalah Pada Materi Asam Basa, Chemistry in Education 4(2) : 64-69

[8] Belland, B., Ertmer, K., and Klein, A., (2006), The Interdisciplinary Journal of Problem-based Learning 1(2) : 1-18

[9] Tasoglu, A.K. and Bakac, M, (2014), The Effect of Problem Based Learning Approach on Conceptual Understanding in Teaching in Teaching of Magnetism Topics, Eurasian Journal of Physics and Chemistry Education 6(2) : 110 - 122

[10] Wulandari, W., F, M.L., dan Supriyanti, T., (2011), Problem Based Learning Untuk Meningkatkan Keterampilan Berpikir Kreatif dan Penguasaan Konsep Siswa Pada Materi Larutan Penyangga, Jurnal Pengajaran MIPA 16(2) : 116-121

[11] Sunaringtyas, K., Saputro, S., dan Masykuri, M., (2015), Pengembangan Modul Kimia Berbasis Masalah Pada Materi Konsepmol Kelas X Sma/Ma Sesuai Kurikulum 2013, Jurnal Inkuiri, 4(2) : $36-46$ 